Article

\title{
Enhanced Selenate Removal in Aqueous Phase by Copper-Coated Activated Carbon
}

\author{
Xinhai Zhao ${ }^{1}$, Aiqing Zhang ${ }^{2}$, Jianhong Zhang ${ }^{3}$, Qipeng Wang ${ }^{1}$, Xuquan Huang ${ }^{1}$, \\ Yonghong $\mathrm{Wu}^{1,4}$ and Cilai Tang ${ }^{1, *}$ \\ 1 College of Hydraulic \& Environmental Engineering, China Three Gorges University, Yichang 443002, China; \\ Zhao_Xh190930@163.com (X.Z.); peterwangkk@163.com (Q.W.); huangxuquan@126.com (X.H.); \\ yhwu@issas.ac.cn (Y.W.) \\ 2 Key Laboratory of Catalysis and Materials Science of the State Ethnic Affair Commission \& Ministry of \\ Education, College of Chemistry and Material Science, South-Central University for Nationalities, \\ Wuhan 430074, China; aiqingzhang_2000@sina.com \\ 3 Resources \& Environment Business Department, International Engineering Consulting Corporation, \\ Beijing 100048, China; KZXlai@163.com \\ 4 State Key Laboratory of Soil and Sustainable Agriculture, Institute of Soil Sciences, Chinese Academy \\ of Sciences, Nanjing 210008, China \\ * Correspondence: bolong@ctgu.edu.cn
}

Received: 16 December 2019; Accepted: 13 January 2020; Published: 19 January 2020

\begin{abstract}
In this study, we prepared a novel sorbent derived from precipitating copper ion onto the surfaces of activated carbon $(\mathrm{Cu}-\mathrm{AC})$. The sorbents were comprehensively characterized by Brunauer-Emmett-Teller (BET), zeta potential analysis, SEM, XRD, and FTIR. Batch experiments were conducted to evaluate selenate removal by $\mathrm{Cu}-\mathrm{AC}$ under different conditions. The results showed that $\mathrm{Cu}$ was uniformly coated on the AC surface. Copper pretreatment markedly decreased the specific surface area and total pore volume of $\mathrm{AC}$, and changed its surface zeta potential from highly negative to low negative and even positive. The $\mathrm{Cu}-\mathrm{AC}$ substantially improved selenate adsorption capacity from the $1.36 \mathrm{mg} \mathrm{Se} / \mathrm{g}$ AC of raw AC to 3.32, 3.56, 4.23, and $4.48 \mathrm{mg}$ Se/g AC after loading of $0.1,0.5,1.0$, and $5 \mathrm{mmol} \mathrm{Cu} / \mathrm{g} \mathrm{AC}$, respectively. The results of toxicity leaching test showed AC coated with $\leq 1.0 \mathrm{mmol} \mathrm{Cu} / \mathrm{g}$ was acceptable for potential application. Selenate adsorption was significantly inhibited by high ionic strength $(>50 \mathrm{mM} \mathrm{NaCl})$ and $\mathrm{pH}(>10)$. The electrostatic attraction between positive surface charge of $\mathrm{Cu}-\mathrm{AC}$ and selenate ions and hydrogen bonding between $\mathrm{CuO}$ and $\mathrm{HSeO}_{4}{ }^{-}$ might contribute to selenate sorption. Evidence showed that the selenate adsorption might involve outer-sphere surface complexation. The adsorption data appeared to be better described by Langmuir than Freundlich isotherm. The spent adsorbent could be effectively regenerated by hydroxide for reuse. Only a little decrease of removal efficiency was observed in the second and third run. This study implies that $\mathrm{Cu}$-coated $\mathrm{AC}$ is a potential adsorbent for sustainable removal selenate from relative low salinity water/wastewater.
\end{abstract}

Keywords: activated carbon; selenate; surface modification; copper; adsorption mechanism

\section{Introduction}

Selenium (Se) is an essential micronutrient for many living organisms but it can also be a potential toxicant to humans, livestock, and plants depending on its chemical species and dose [1-3]. Selenium in various forms and concentrations has been found in agricultural drainage and industrial wastewaters, such as thermoelectric power generation, mining, and refinery industries $[4,5]$. The increasing concerns over Se contamination from the wastewater of wet flue-gas-desulfurization (FGD) systems of coal-fired power plants have attracted more attention of the government and public [5]. The maximum level of 
Se in drinking water is $10 \mu \mathrm{g} / \mathrm{L}$ in many countries including China. Among many forms of Se, selenate $\left(\mathrm{SeO}_{4}{ }^{2-}\right)$ is one of the most concerning forms because of its high chemical stability, mobility and bioavailability, and weak adsorption affinity to particles surface in the environment [6]. In principle, immobilization of Se can be achieved by sorption, coagulation, precipitation and ion exchanges, or by chemical and biological reduction processes [2,5,7]. Several anaerobic biological treatment processes have been developed as a solution to treat selenate contaminated mining drainage and FGD wastewater [8]. But the high costs, complexity, and other problems associated with the biological technologies are the major concerns and obstacles. Moreover, the production of more bioavailable organic Se after biological treatment is a potential harm to the environment [9]. Therefore, finding a reliable and cost-effective Se solution is still a major challenge to water industry.

Sorption is a very cost-effective and simple process for environmental contamination cleanup. Activated carbon (AC) is a very easily available and cost-effective adsorbent for contamination removal [10]. AC has been proven to be effective for adsorbing and removing a variety of organic and inorganic contaminants from aqueous and gas phase environments [11,12]. Most of studies focused on enhancing $A C^{\prime}$ 's adsorption capacity for specific contaminants by modifying its surface properties via chemical, physical, or biological methods $[13,14]$. Activated carbon impregnated with transition metals (e.g., $\mathrm{Fe}, \mathrm{Al}, \mathrm{Cu}$, and $\mathrm{Ag}$ ) oxides has been used to enhance anionic contaminants removal [15-17]. Generally, two methods have been used to develop a metal-impregnated AC: (1) $\mathrm{pH}$-induced precipitation of metal ions; and (2) adsorption of metal ions onto AC surface followed by heat treatment $[17,18]$. The $\mathrm{pH}$ method has been used more widely than the adsorption-heat treatment due to its simpler operation process and exact content of metal ion coating. It can be loaded for any amount of metal ion on AC. Generally, the adsorption of selenate onto virgin AC is very poor $[18,19]$. Iron, due to its relatively low environmental risk, was the most widely used transition metal to modify AC for Se removal [17,20,21]. But only selenite effective removal has been reported in previous studies by iron-impregnated AC [18,20,22]. Recently, however, copper increasingly attracted more attention as an impregnant for AC modification towards contaminants removal [23-27]. Copper oxide $(\mathrm{CuO})$ nanoparticles impregnated $\mathrm{AC}$ decreased its $\mathrm{pH}_{\mathrm{pzc}}$ and, thus, obviously promoted the adsorption capacity of atrazine, caffeine, diclofenac, and nitrate onto AC [26]. Hu et al. reported that copper-impregnated AC showed the best adsorption performance for ceftazidime rather than iron and aluminum [24]. Compared to $\mathrm{Ni}, \mathrm{Fe}$, and $\mathrm{Co}, \mathrm{Cu}$ modified $\mathrm{AC}$ produced more active groups and was beneficial to activate the active component of $\mathrm{AC}$, and thus exhibited the best $\mathrm{Hg}(0)$ removal efficiency [27]. Previous studies also showed that copper loaded AC significantly enhanced its adsorption capacity towards methylene blue [28], dyes [25,29], iodide ion [30], nitrate [26], and toxic gases $\left(\mathrm{H}_{2} \mathrm{~S}\right.$ and $\left.\mathrm{SO}_{2}\right)$ [23]. But few studies have investigated the copper-coated AC for Se sorption, especially for selenate.

In our preliminary experiments, copper-coated AC achieved the best removal efficiency (99.9\%) for selenate compared to the ACs coated with same amount ( $3 \mathrm{mmol} / \mathrm{g} \mathrm{AC}$ ) of iron(III), aluminum, and cobalt, which achieved 69\%,63\%, and 87\% removal, respectively. Moreover, this four metal ion pretreatment was better than $\mathrm{H}_{2} \mathrm{O}_{2}$ and $\mathrm{HNO}_{3}$ pretreatment, both of which only achieved $57 \%$ and $60 \%$ of selenate removal, respectively. Therefore, batch experiments were conducted to comprehensively probe selenate sorption by $\mathrm{Cu}$-coated AC under different conditions.

The objectives of this study were to: (1) evaluate selenate adsorption onto Cu-coated AC through batch experiments under different operational conditions; and (2) elucidate the mechanism(s) involved through analyses and characterization of physicochemical properties of copper-coated AC and its interactions with selenate by SEM, XRD, FTIR, Brunauer-Emmett-Teller (BET), and zeta potential measurements. 


\section{Materials and Methods}

\subsection{Materials}

All chemicals used in this study were of analytical reagent grade. The powder activated carbon was supplied by Strem Chemicals. As a pretreatment process, the AC was washed three times with de-ionized water (DI) to remove impurities, oven-dried at $105^{\circ} \mathrm{C}$ for $24 \mathrm{~h}$, and then stored in a plastic container for further modification. Selenate $\left(\mathrm{Na}_{2} \mathrm{SeO}_{4},>99.8 \%\right)$ stock solution was prepared using deoxygenated DI water. Dissolved oxygen (DO) was eliminated from the DI water by nitrogen gas purging and stored in an anaerobic chamber for use. Copper sulfate $\left(\mathrm{CuSO}_{4} \cdot 4 \mathrm{H}_{2} \mathrm{O}, 99.8 \%\right)$ was used to prepare $\mathrm{Cu}$-coated $\mathrm{AC}$.

\subsection{Preparation of $\mathrm{Cu}$-Coated Activated Carbon}

Fifteen (15) gram pre-cleaned AC powders were mixed with $300 \mathrm{~mL} \mathrm{CuSO}_{4}$ solution of 5, 25, 50, or $250 \mathrm{mM}$ in a $500 \mathrm{~mL}$ beaker to examine the effect of $\mathrm{Cu}$ concentration on selenate removal, which resulted in a mass ratio of copper to $\mathrm{AC}$ at $0.1,0.5,1.0$, and $5.0 \mathrm{mmol} \mathrm{Cu^{2+ }}$ per gram $\mathrm{AC}$, respectively. After 5.0 min agitation, the suspension was slowly titrated with $1.0 \mathrm{M} \mathrm{NaOH}$ solution to the $\mathrm{pH}$ of 7.0 for complete precipitation of $\mathrm{Cu}^{2+}$ as $\mathrm{Cu}(\mathrm{OH})_{2}$. No aqueous $\mathrm{Cu}^{2+}$ was detected after $\mathrm{NaOH}$ treatment. The resultant suspension was filtered and then washed with DI water until $\mathrm{SO}_{4}{ }^{2-}$ was below $<1.0 \mathrm{ppm}$ in the supernatant. The washed AC was dried at $105^{\circ} \mathrm{C}$ overnight. Upon cooling, the copper-coated $\mathrm{AC}$ was rinsed again with DI and dried at $105^{\circ} \mathrm{C}$, then comminuted and stored in plastic bottles for use.

\subsection{Characterization of Activated Carbon}

Surface morphology of the AC before and after copper treatment was characterized using a scanning electron microscope (Quanta 600 FE-SEM, JOEL, Tokyo, Japan) at a voltage of $20 \mathrm{kV}$. The SEM is equipped with an energy dispersion spectrometer (EDS) detector that can perform elemental analysis. Specific surface area and total pore volume of the AC were analyzed with a NOVA surface area and pore size analyzer (4200e, Quantachrome Instruments, Phoenix, EDAX, Mahwah, NJ, USA) using the BET nitrogen adsorption method. Surface zeta potential was measured by the electrophoretic method using a Malvern Zetasizer Nano ZS (Phoenix, EDAX, Mahwah, NJ, USA) while ultrapure DI water was used as the dispersant without $\mathrm{pH}$ adjustment. X-ray diffraction (XRD) (Rigaku Ultima IV, Kyoto, Japan) using $\mathrm{Cu} \mathrm{K \alpha}$ radiation was used to determine the copper compounds. Fourier transform infrared spectroscopy (FTIR) (NEXUS, Thermo Electron, Waltham, MA, USA) was used to detect the detailed properties of AC surface functional groups before and after modification.

\subsection{Batch Experiments}

The selenate adsorption experiments were conducted in serum bottles with an effective volume of $10 \mathrm{~mL}$. Firstly, a predetermined amount of Cu-coated AC (e.g., $0.10 \mathrm{~g}$ ) was placed in the serum bottles. The bottles were then transferred into an anaerobic chamber which was filled with an air of approximately $97 \% \mathrm{~N}_{2}$ and $3 \% \mathrm{H}_{2}$ and equipped with a palladium catalytic oxygen removal system and an oxygen detector (Coy Laboratory, Mahwah, NJ, USA). Then, $10 \mathrm{~mL}$ diluted selenate solution was added to the bottles using pipettor, which created the initial condition of $10 \mathrm{~g} / \mathrm{L} \mathrm{AC} \mathrm{mixing} \mathrm{with}$ selenate of a specific concentration. The bottles were capped with a rubber stopper and sealed tightly with an aluminum crimp. Then they were transferred into a rotary shaker for complete mixing at $30 \mathrm{rpm}$ at room temperature $\left(22 \pm 2{ }^{\circ} \mathrm{C}\right)$ in the dark. No pH adjustment was performed unless specified otherwise. At designated time interval, two bottles (duplicate) were withdrawn from the shaker and sacrificed for $\mathrm{pH}$ and selenate analyses after filtering with a $0.45 \mu \mathrm{m}$ membrane filter.

In order to evaluate the effect of initial $\mathrm{pH}$ on selenate adsorption, $0.5 \mathrm{~mol} \mathrm{HCl}$ or $\mathrm{NaOH}$ mol solutions were used to adjust the initial $\mathrm{pH}$ of the mixed suspension to $\mathrm{pH} 4.0,5.0,6.0,7.0,8.0,9.0$, or 10.0. Ionic strength was adjusted by adding $\mathrm{NaCl}$ stock solution to achieve $10,25,50,75$, or $100 \mathrm{mM}$ $\mathrm{NaCl}$. Toxicity characteristic leaching procedure (TCLP) was conducted to assess copper release 
following the U.S. EPA TCLP method 1311 using a pH 4.93 extractant prepared from glacial acid and sodium hydroxide.

Another set of the desorption experiment was performed to evaluate the adsorbent regeneration using $1.0 \mathrm{mmol} \mathrm{Cu} / \mathrm{g} \mathrm{AC}$. After reaching adsorption equilibrium, the suspension was filtered and collected filtrate for selenate measurement. The residual solid was rinsed twice with $5.0 \mathrm{~mL}$ DI water each time. The suspension was passed through the same filter membrane to collect all AC solid. But the filtrate was discarded. The filter membrane containing solid was then put back into previous bottle, and followed by adding $10 \mathrm{~mL} 0.10 \mathrm{M} \mathrm{NaOH}$. The bottle was sealed tightly and transferred into the rotary shaker for complete mixing to extract adsorbed selenate. In order to investigate the effect of extracting time on the extracting efficiency of adsorbed selenate, 4, 10, 20, and $30 \mathrm{~h}$ were chosen as the shaking time. An extracting time of $4 \mathrm{~h}$ was recommended in literature to desorb selenate sorption onto iron oxides [31]. Moreover, the reuse trial of the regenerated $\mathrm{Cu}-\mathrm{AC}$ was also performed similar to new adsorbent test, except that the initial suspension $\mathrm{pH}$ was adjusted to seven using $0.1 \mathrm{M} \mathrm{HCl}$ because $\mathrm{NaOH}$ was added to extract adsorbed selenate.

\subsection{Analytical Methods}

Selenate in the filtrate was measured using a Dionex DX 500 model ion chromatographer (IC, ThermoFisher Scientific, Waltham, MA, USA) equipped with an autosampler and a CD20 conductivity detector. Separation was achieved using a Dionex IonPac AS-22 column (4 by $250 \mathrm{~mm}$ ) and an AG-22 guard column ( 4 by $50 \mathrm{~mm}$ ). The eluent solution $\left(4.5 \mathrm{mM} \mathrm{Na}_{2} \mathrm{CO}_{3}\right.$ and $1.4 \mathrm{mM} \mathrm{NaHCO}$ ) was pumped at a flow rate of $1.5 \mathrm{~mL} / \mathrm{min}$. The detection limit of the IC for selenate was $20 \mu \mathrm{g} / \mathrm{L}$ as Se. Dissolved copper in the leachate was also analyzed with the IC system using an IonPac CS5A 4 by $250 \mathrm{~mm}$ separation column and a UV-Vis detector (AD 20). The flow rate of the eluent (MetPac PDCA) and the MetPac post column reagent were $1.0 \mathrm{~mL} / \mathrm{min}$ and $0.5 \mathrm{~mL} / \mathrm{min}$, respectively. $\mathrm{pH}$ value was measured using an ORION $\mathrm{pH}$ meter and probe.

\section{Results and Discussion}

\subsection{Characteristics of the Adsorbents}

As shown in Figure 1, the surface morphology of the AC particles varied a lot before and after $\mathrm{Cu}$ coating. The virgin AC surface was smooth, porous and rugged (Figure 1a). After $\mathrm{Cu}$ coating at a dosage of $0.1 \mathrm{mmol} C \mathrm{C}$ per gram AC (Figure $1 \mathrm{~b}$ ), the AC surface was sporadically and uniformly deposited with small white particulate matters that were identified as a copper-bearing substance by EDS analysis (data not shown). The copper particles seem to be nanosized, in the range of $<0.5 \mu \mathrm{m}$. It indicated that copper was homogeneously coated on the AC surface. More $\mathrm{Cu}$-containing compound deposit on the AC surface was observed with increasing $\mathrm{Cu}$ dosage loading. A sectional flocculent coating at $1.0 \mathrm{mmol} \mathrm{Cu} / \mathrm{g} \mathrm{AC} \mathrm{(Figure} \mathrm{1c)} \mathrm{and} \mathrm{a} \mathrm{thick} \mathrm{and} \mathrm{full} \mathrm{coverage} \mathrm{on} \mathrm{AC} \mathrm{surface} \mathrm{at} 5.0 \mathrm{mmol} \mathrm{Cu} / \mathrm{g}$ AC (Figure 1d) was observed. The copper compounds form was identified using XRD (Figure 2a). Copper oxide was the dominant $\mathrm{Cu}$-containing compound with $0.1 \mathrm{mmol} \mathrm{Cu} / \mathrm{g} \mathrm{AC}$ coating. But $\mathrm{CuO}$, $\mathrm{Cu}(\mathrm{OH})_{2}$, and $\mathrm{Cu}_{4}(\mathrm{OH})_{6} \mathrm{SO}_{4}$ were co-present with 1.0 and $5.0 \mathrm{mmol} \mathrm{Cu} / \mathrm{g}$ AC coating. It implied that $\mathrm{SO}_{4}{ }^{2-}$ from $\mathrm{CuSO}_{4}$ coprecipitated with $\mathrm{Cu}(\mathrm{OH})_{2}$. 


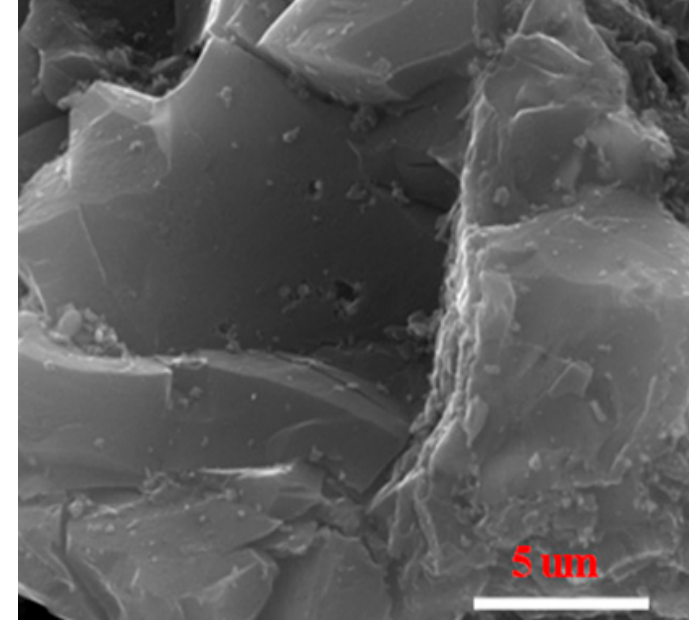

(a)

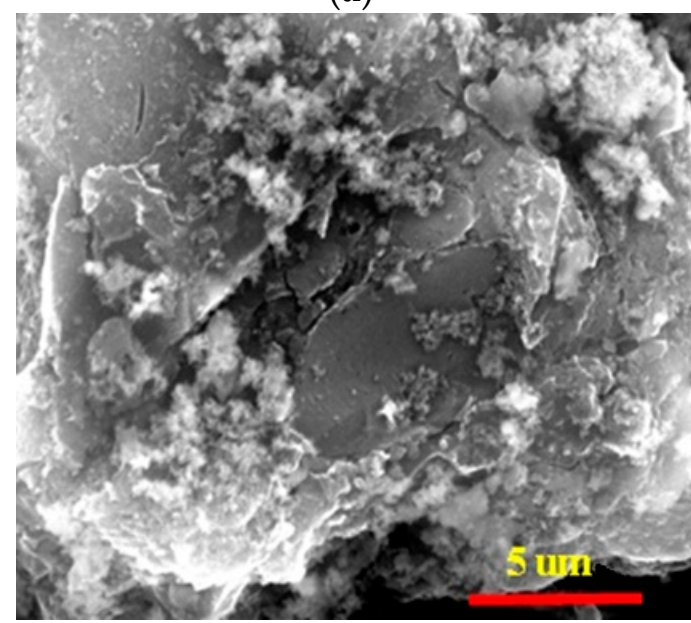

(c)

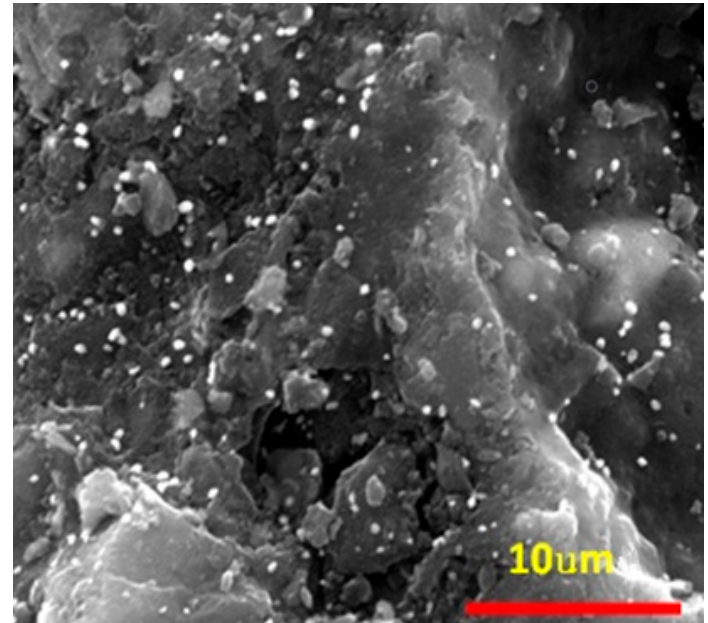

(b)

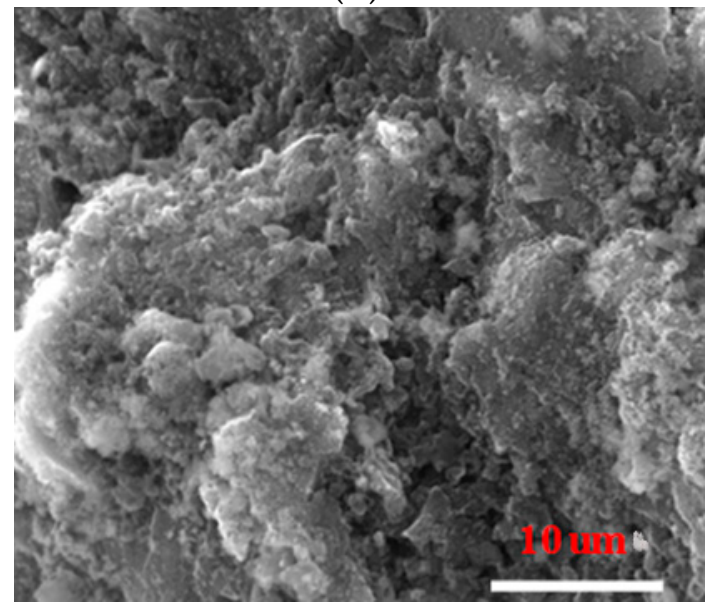

(d)

Figure 1. (a) SEM images of the raw and copper-coated activated carbon with a copper dosage of (b) 0.1 , (c) 1.0 , and (d) $5.0 \mathrm{mM} \mathrm{Cu} / \mathrm{g}$ AC.

The materials were also characterized by BET specific surface area analysis $\left(\mathrm{S}_{\mathrm{BET}}\right)$, micropore area $\left(S_{\text {micro }}\right)$, micropore volume $\left(V_{\text {micro }}\right)$, total pore volume $\left(V_{\text {total }}\right)$, and average pore diameter $\left(D_{p}\right)$. The results are shown in Table 1 . It could be seen that pure AC has a high specific surface area, and it gradually decreased with the increasing of copper coating dosage. The specific surface area of AC coated with $5 \mathrm{mmol} \mathrm{Cu} / \mathrm{g}$ was only half of the raw AC. Similarly, the micropore area, micropore volume, and total pore volume also decreased compared to raw AC. It is possible due to the partial micropore obstruction by copper compounds, which was consistent with previous report [26]. As observed in SEM pattern in Figure 1, the copper precipitates appeared to fill up or clog a substantial portion of the micro-pores within the AC grains and thus reduce both the porosity and specific surface area of the AC. Such a decrease in pore volume and specific surface area after metal impregnation was also observed in previous studies on copper-impregnated AC [18,24,32-34], iron-impregnated AC [21,35], and oxidant-modified AC [36]. However, the average pore diameter increased slowly with more copper coating. Similar existence was also observed after copper modification [27]. Zeta potential is a measure of the magnitude of the electrostatic or charge repulsion/attraction between particles and is one of the fundamental parameters known to affect stability. The surface zeta potential ( $\left.E_{\text {zeta }}\right)$ of the raw AC was highly negative. Although the copper coating markedly decreased the negative charge of $\mathrm{AC}$ with increasing $\mathrm{Cu}$ dosage, it was still negatively charged when $\mathrm{Cu}$ dosage was below $1 \mathrm{mmol}$ $\mathrm{Cu} / \mathrm{g} \mathrm{AC}$. It was positively charged after coating with 1 and $5 \mathrm{mmol} \mathrm{Cu/g} \mathrm{AC}$. Therefore, with the 
higher dosage of copper coating, a higher positive of surface charge occurred. As the variation of the surface charge, the electrostatic interaction between the selenate and AC could change completely. For selenate, the interaction force between selenate and the $\mathrm{AC}$ would change from electrostatic repulsive to attractive and thereby significantly increase the surface affinity of selenate. Generally, the $\mathrm{pH}$ at point of zero charge $\left(\mathrm{pH}_{\mathrm{pzc}}\right)$ of activated carbon was approximately four to five, and it increased to seven to nine after modification using metal cations or metal oxides [18,26,28,32,33]. The zeta potential depends on surface charge. And the zeta potential determined the $\mathrm{pH}_{\mathrm{pzc}}$. More negative zeta potential implied it needed more positive charge (e.g., $\mathrm{H}^{+}$) to neutralize it and its $\mathrm{pH}_{\mathrm{pzc}}$ would be more acidic, vice versa.

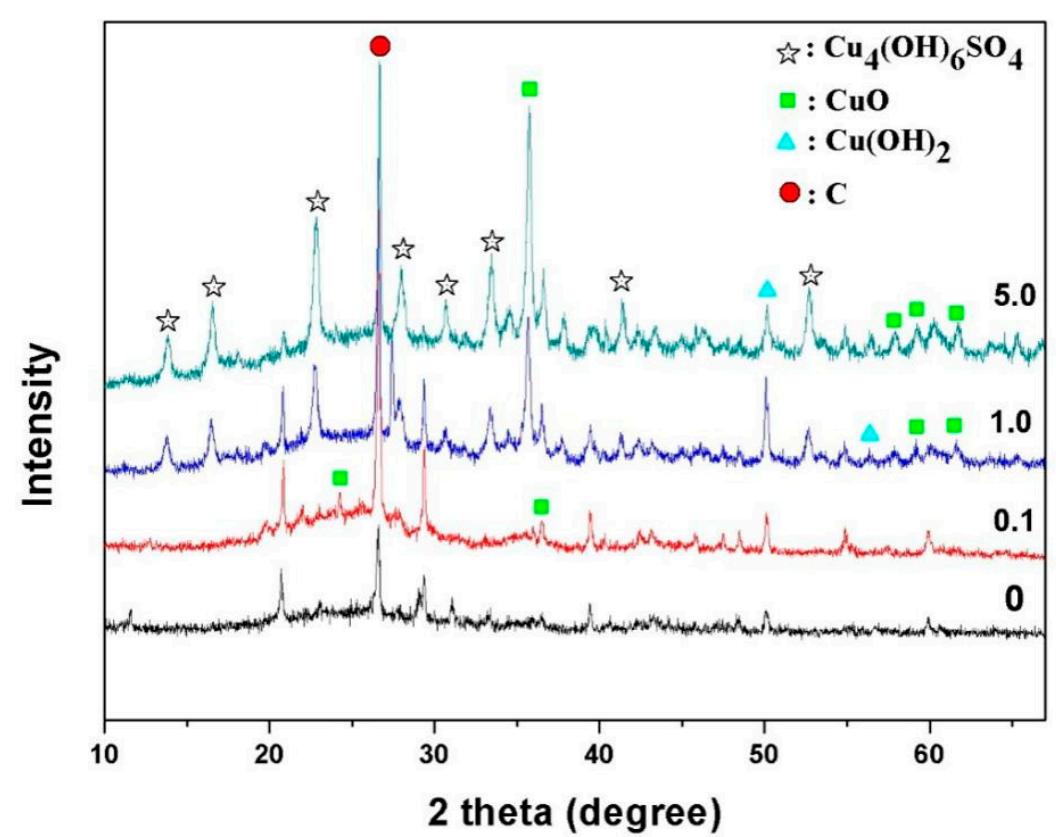

(a)

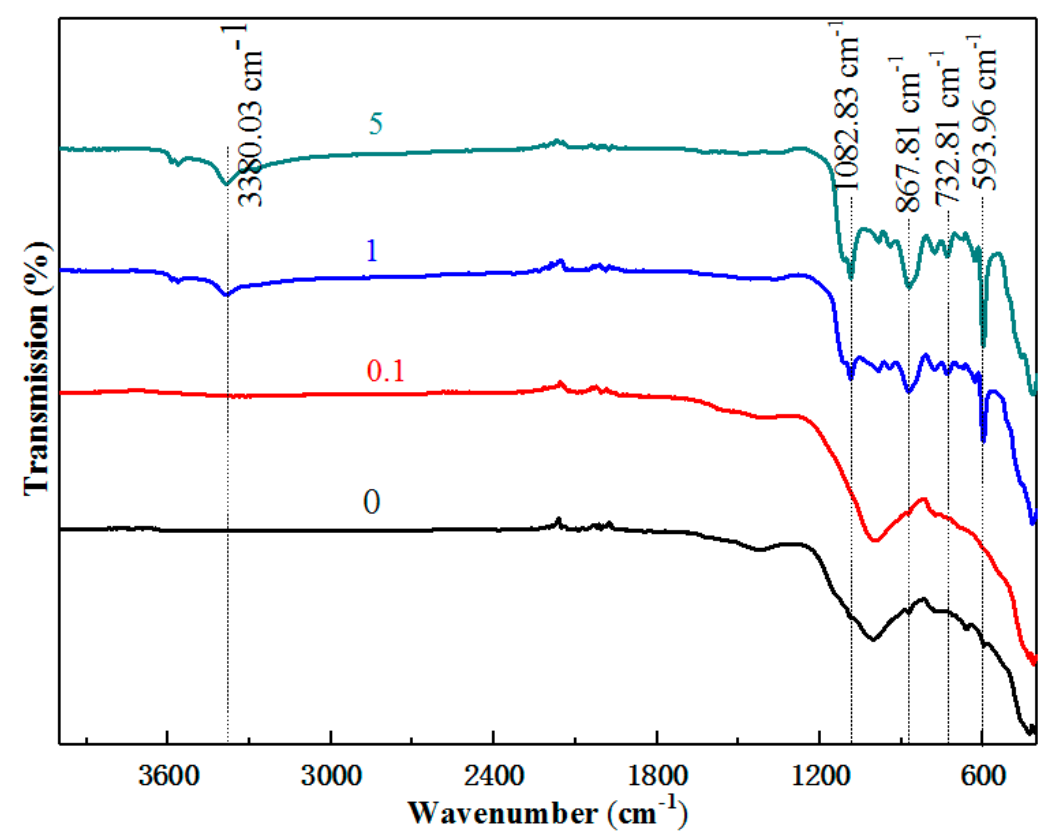

(b)

Figure 2. XRD patterns (a) and FTIR spectra (b) of activated carbon before and after Cu-coating with different dosage of copper loading. 
Table 1. Textural characterization parameters and zeta potential of different sorbent.

\begin{tabular}{ccccccc}
\hline Adsorbent & $\mathbf{S}_{\text {BET }}\left(\mathbf{m}^{2} / \mathbf{g}\right)$ & $\mathbf{S}_{\text {micro }}\left(\mathbf{m}^{2} / \mathbf{g}\right)$ & $\mathbf{V}_{\text {total }}\left(\mathbf{c m}^{3} / \mathbf{g}\right)$ & $\mathbf{D}_{\mathbf{p}}(\mathbf{n m})$ & $\mathbf{E}_{\text {zeta }}(\mathbf{m V})$ & $\mathbf{V}_{\text {micro }}\left(\mathbf{c m}^{3} / \mathbf{g}\right)$ \\
\hline 0 & 1335 & 1135 & 0.574 & 1.62 & -48.34 & 0.472 \\
0.1 & 1254 & 1028 & 0.552 & 1.81 & -32.24 & 0.49 \\
0.5 & 1246 & 1002 & 0.536 & 1.79 & -10.52 & 0.483 \\
1.0 & 1132 & 885 & 0.490 & 1.85 & 5.48 & 0.452 \\
5.0 & 679.1 & 475 & 0.326 & 1.92 & 24.80 & 0.274 \\
\hline
\end{tabular}

The surface functional groups of AC treated with different dosage of $\mathrm{Cu}$ loading were investigated by FTIR (Figure $2 b$ ). The small peak at around $3380 \mathrm{~cm}^{-1}$ was attributed to $-\mathrm{OH}$ stretching vibration in AC treated with 1 and $5 \mathrm{mmol} \mathrm{Cu} / \mathrm{g}$ [37]. But no peak at this area was observed for raw $\mathrm{AC}$ and modified with a little of $\mathrm{Cu}$ loading (0.1). It was possible due to complete dehydration of $\mathrm{Cu}(\mathrm{OH})_{2}$ during drying in the presence of small dosage of $\mathrm{Cu}$ loading, but it was only partly dehydrated for more thick Cu coating ( 1 and $5 \mathrm{mmol}$ ). The blunt peak at around $1000 \mathrm{~cm}^{-1}$ was possibly attributed to sulfonic acids and salts in raw and low $\mathrm{Cu}$ loading AC [38], but it almost disappeared with more $\mathrm{Cu}$ coating. New peaks at around 1082,867 , and $594 \mathrm{~cm}^{-1}$ were attributed to the vibration of $\mathrm{Cu}-\mathrm{O}$ after coating with more $\mathrm{Cu}$ loading $[39,40]$. Among them, the peak at $594 \mathrm{~cm}^{-1}$ was associated with longitudinal optical vibrational mode of $\mathrm{Cu}-\mathrm{O}$ [40]. More peaks in the area of $600-1200 \mathrm{~cm}^{-1}$ in the $\mathrm{Cu}-\mathrm{AC}$ implied that more surface specific functional groups existed after coating more $\mathrm{Cu}$ dosage, and thus more favorable selenate adsorption. Previous study found more peaks in the area of $800-1000 \mathrm{~cm}^{-1}$ after copper modification, and they proposed that copper-modified activated carbon produced more reactive atoms on the adsorbent surface and more vacant reactive metallic or semi-metallic centers, which remarkably enhanced its adsorption capacity towards methylene blue dye [25].

\subsection{Effect of Copper Coating Dosageon Selenate Removal}

As shown in Figure 3a, it markedly increased selenate removal efficiency with increasing dosage of $\mathrm{Cu}$ coating. The raw AC could only achieve $27 \%$ selenate removal after equilibrium. In comparison, the $\mathrm{Cu}-\mathrm{AC}$ achieved selenate removals of $67 \%, 71 \%, 81 \%$, and $88 \%$ with copper dosages of $0.1,0.5$, 1.0 , and $5.0 \mathrm{mmol} / \mathrm{g} \mathrm{AC}$, respectively. The increase in selenate removal by $\mathrm{Cu}-\mathrm{AC}$ was achieved despite the decrease in the sorbent's specific surface area and total pore volume after $\mathrm{Cu}$ impregnation (Table 1). The $\mathrm{Cu}$ treatment, however, changed the surface zeta potential from highly negative to low negative and even positive, which might be responsible for the promotion effect of adsorption capacity. This observation was in agreement with several previous studies on selenite sorption onto iron-coated AC [35], propanethiol adsorption onto copper-coated AC [33], and $\mathrm{Cr}(\mathrm{VI})$ adsorption onto $\mathrm{HNO}_{3}$-modified AC [36]. Compared to $10 \%(\mathrm{w} / \mathrm{v})$ iron-coated $\mathrm{AC}$ [32], $15.6 \mathrm{mmol} \mathrm{Cu} / \mathrm{g} \mathrm{AC} \mathrm{[30]} \mathrm{and}$ $0.25-1.5 \mathrm{~mol} \mathrm{Cu} / \mathrm{g} \mathrm{AC} \mathrm{[41],} \mathrm{the} \mathrm{dosage} \mathrm{of} \mathrm{Cu}$ coating $(0.1-5.0 \mathrm{mmol} \mathrm{Cu} / \mathrm{g} \mathrm{AC})$ on AC in this study is not high. Although no dissolved copper release was detected during the whole period of sorption with all $\mathrm{Cu}-\mathrm{AC}$, the possible release of copper ion in the long-term application may pose potential risk to human and ecosystem health. Hence, the toxicity characteristic leaching procedure (TCLP, Madison, WI, America; EPA Test Method 1311) protocol on Cu-AC was conducted to assess its potential risk. The TCLP results showed that the extraction leaching contained $0.2,4.5,12.6$, and $56.8 \mathrm{mg} / \mathrm{L}$ dissolved copper for the $\mathrm{Cu}-\mathrm{AC}$ coated with $0.1,0.5,1.0$, and $5.0 \mathrm{mmol} \mathrm{Cu} / \mathrm{g} \mathrm{AC}$, respectively. The total copper content in the leachate of hazardous solid waste is $50 \mathrm{mg} / \mathrm{L}$ in China. Moreover, the soluble threshold limit concentration (STLC) of $\mathrm{Cu}$ is $25 \mathrm{mg} / \mathrm{L}$ in USA. Hence, AC coated with $\leq 1.0 \mathrm{mmol}$ $\mathrm{Cu} / \mathrm{g}$ is an acceptable adsorbent for potential application. The spent adsorbent can be disposed as a non-hazardous solid. In order to further evaluate the effect of other operation parameters on potential application in the future, $\mathrm{Cu}$-coated $\mathrm{AC}$ with $1.0 \mathrm{mmol} \mathrm{Cu} / \mathrm{g} \mathrm{AC}$ was chosen as the adsorbent for the next experiments. 


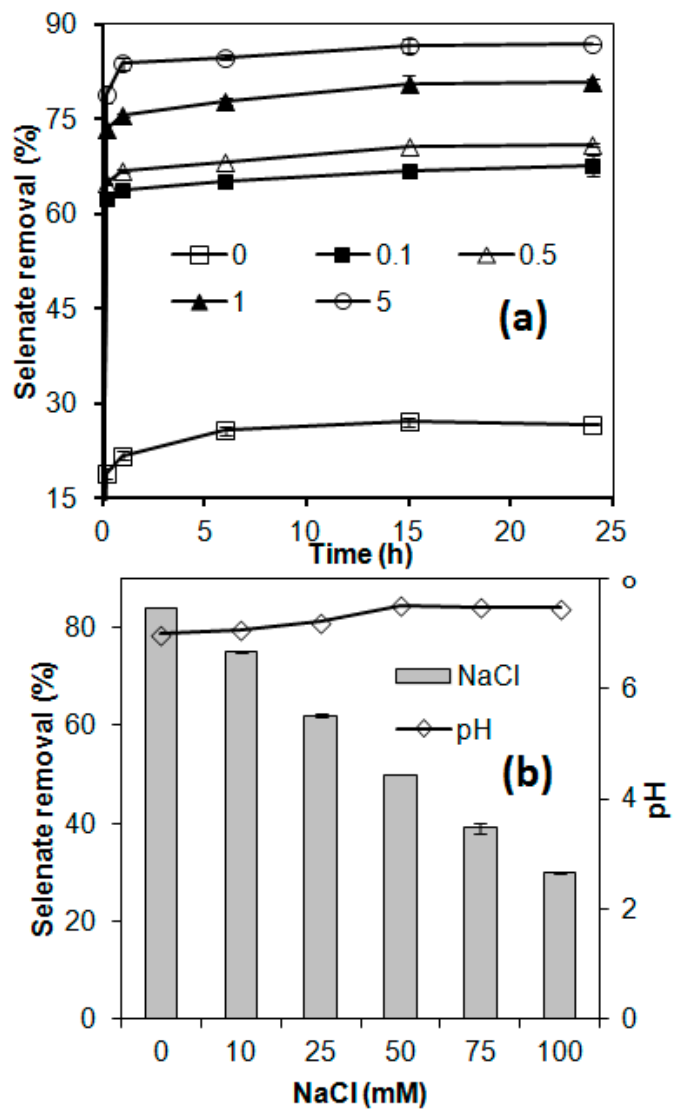

Figure 3. Effect of (a) copper coating dosage [0 (raw), 0.1, 0.5, 1.0, and $5.0 \mathrm{mmol} \mathrm{Cu/g} \mathrm{AC]} \mathrm{on} \mathrm{selenate}$ adsorption; and (b) solution ionic strength on selenate adsorption on copper-coated activated carbon, and the solution $\mathrm{pH}$ after adsorption, with an initial $\mathrm{pH} \sim 7.0$.

\subsection{Effect of Ionic Strength}

Generally, high ionic strength would inhibit target contaminants adsorption in aqueous phase due to competition. Many of previous studies only employed a very low salinity $(\leq 5 \mathrm{mM})$ to probe the impact of ionic strength or co-present ion on contaminants adsorption by modified AC [35,42,43]. It is not accurate to evaluate the effect of ionic strength on adsorption, because the salinity in real water/wastewater is much higher than it. Therefore, a higher salinity $(0-100 \mathrm{mM})$ was performed to investigate the effect of ionic strength on selenate adsorption onto $\mathrm{Cu}-\mathrm{AC}$ in this study. The result in Figure $3 \mathrm{~b}$ showed that ionic strength significantly inhibited the adsorption of selenate onto the $\mathrm{Cu}-\mathrm{AC}$. The increase of ionic strength reduced selenate adsorption onto the $\mathrm{Cu}-\mathrm{AC}$. Selenate removal dropped substantially from $84 \%$ to $75 \%$ when $10 \mathrm{mM} \mathrm{NaCl}$ was present. It was further reduced to $62.5 \%, 50.3 \%$, $39.7 \%$, and $30.5 \%$ when $25 \mathrm{mM}, 50 \mathrm{mM}, 75 \mathrm{mM}$, and $100 \mathrm{mM} \mathrm{NaCl}$ was added, respectively. The added $\mathrm{NaCl}$ was corresponding to the salt content of $0.59,1.46,2.9,4.39$, and $5.85 \mathrm{~g} / \mathrm{L}$, respectively. This salinity is comparable to most of moderate polluted water/wastewater. A small increase of $\mathrm{pH}$ was observed with increasing $\mathrm{NaCl}$ addition, possibly due to the exchange of $\mathrm{Cl}^{-}$with $\mathrm{OH}^{-}$on $\mathrm{Cu}-\mathrm{AC}$ surface, because the presence of $\mathrm{OH}^{-}$for coating $1.0 \mathrm{mmol} \mathrm{Cu} / \mathrm{g}$ AC was proved by FTIR (Figure $2 \mathrm{~b}$ ). It showed that ionic strength not $\mathrm{pH}$ was the major reason for poor selenate removal. This implied that an outer-sphere complexation, which was sensitive to ionic strength, for selenate adsorption onto $\mathrm{Cu}-\mathrm{AC}$ was the most possible mechanism. A previous study suggested that outer-sphere complex was a weakly-bonded affinity and could be weakened remarkably with increasing ionic strength [44]. Such negative impacts of ionic strength on contaminants adsorption was also observed in previous studies on selenate adsorption onto iron oxides/hydroxides [45], iron-coated AC [21], and iodide sorption onto $\mathrm{Cu}-\mathrm{AC}[30]$. The results suggested that the $\mathrm{Cu}$-coated $\mathrm{AC}$ might not be effective for selenate removal 
from certain wastewaters containing high dissolved salts but might be effective for relative low salinity (e.g., $<50 \mathrm{mM}$ ionic strength) water/wastewater.

\subsection{Effect of Initial $\mathrm{pH}$}

Figure 4a shows how initial $\mathrm{pH}$ affected the efficiency of selenate adsorption by $\mathrm{Cu}-\mathrm{AC}$. The maximum adsorption was observed at $\mathrm{pH}$ 6.0. Lower or higher $\mathrm{pH}$ would inhibit selenate removal by $\mathrm{Cu}-\mathrm{AC}$. Previous studies also showed that selenate adsorption onto iron oxides [45], iron-coated $\mathrm{AC}$ [43], and ceftazidime sorption onto $\mathrm{Cu}-\mathrm{AC}$ [24] decreased with increasing $\mathrm{pH}$. But the lower selenate removal in the $\mathrm{pH}$ range of four to six might partly result from the negative effect of ionic strength as shown in Figure $3 \mathrm{~b}$, because $13.56 \mathrm{mM} \mathrm{Cl}^{-}$from $\mathrm{HCl}$ for adjusting initial $\mathrm{pH}$ to 4.0 was detected. Moreover, although lower $\mathrm{pH}(4-6)$ might increase the positive charge of $\mathrm{Cu}-\mathrm{AC}$, it also decreases the negative charge of selenate $\left(\mathrm{SeO}_{4}{ }^{2-} \rightarrow \mathrm{HSeO}_{4}{ }^{-}\right)$, and thus it decreased their attractive force [20]. Additionally, the $\mathrm{pH}$ changes before and after adsorption equilibrium was obtained. As shown in Figure $4 \mathrm{~b}$, the $\mathrm{pH}$ at initial values of 4.0, 5.0, and 6.0 increased to 4.9, 5.13, and 6.15 after adsorption equilibrium, respectively. The increase of $\mathrm{pH}$ implied the exchange of $\mathrm{SeO}_{4}{ }^{2-}$ and $\mathrm{OH}^{-}$on $\mathrm{Cu}-\mathrm{AC}$ and the release of $\mathrm{OH}^{-}$. As the initial $\mathrm{pH}$ above 7.0, the final $\mathrm{pH}$ decreased possible due to $\mathrm{OH}^{-}$adsorption onto $\mathrm{Cu}-\mathrm{AC}$. The similar variation of $\mathrm{pH}$ before and after $\mathrm{I}^{-}$adsorption onto $\mathrm{Cu}-\mathrm{AC}$ was observed [30].

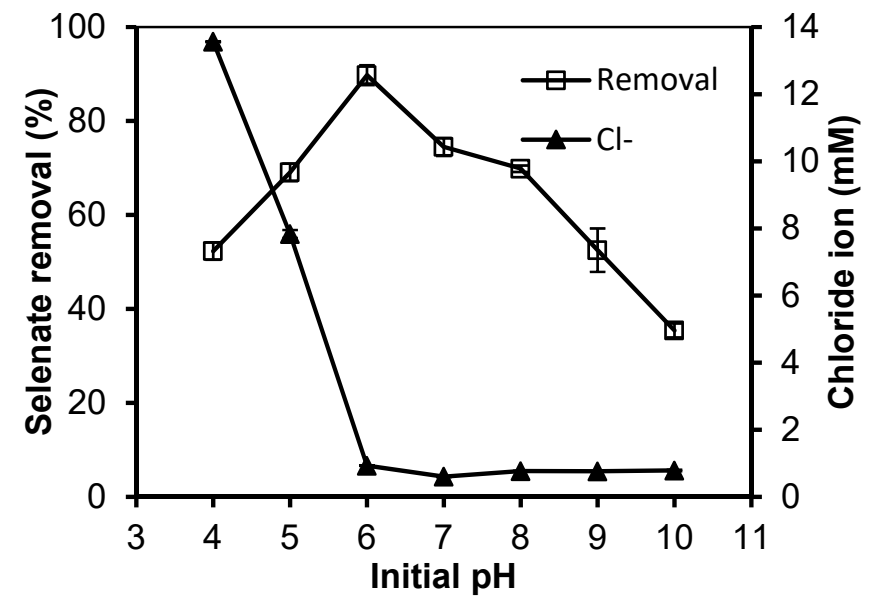

(a)

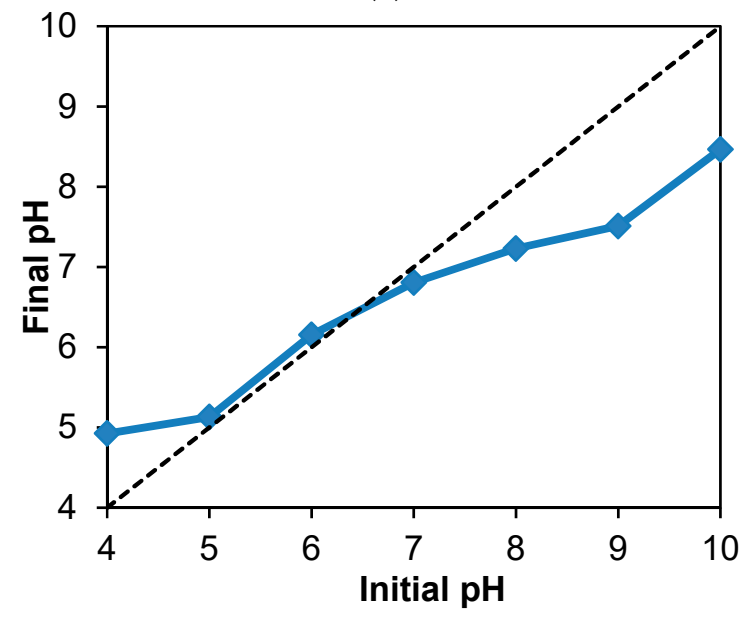

(b)

Figure 4. Effect of initial solution $\mathrm{pH}$ on (a) selenate adsorption onto $\mathrm{Cu}-\mathrm{AC}$, and (b) the final $\mathrm{pH}$ after adsorption. 
The strong dependence of adsorption on $\mathrm{pH}$ and ionic strength suggested that outer-sphere complexation might be the dominant mechanism for selenate adsorption onto $\mathrm{Cu}-\mathrm{AC}$. The possible adsorption pathways could be described by the following equations:

$$
\begin{aligned}
& \equiv \mathrm{Cu}-\mathrm{OH}+\mathrm{H}^{+}+\mathrm{SeO}_{4}{ }^{2-} \leftrightarrow \equiv \mathrm{Cu}-\mathrm{OH}_{2}{ }^{+}-\mathrm{SeO}_{4}{ }^{2-} \text { (electrostatic attraction) } \\
& \equiv \mathrm{Cu}-\mathrm{O}+\mathrm{H}^{+}+\mathrm{SeO}_{4}{ }^{2-} \leftrightarrow \equiv \mathrm{Cu}-\mathrm{OH}^{+}-\mathrm{SeO}_{4}{ }^{2-} \text { (electrostatic attraction) } \\
& \equiv \mathrm{Cu}-\mathrm{OH}+\mathrm{SeO}_{4}{ }^{2-} \leftrightarrow \equiv \mathrm{Cu}-\mathrm{SeO}_{4}{ }^{-}+\mathrm{OH}^{-} \text {(ion exchange) } \\
& \equiv \mathrm{Cu}-\mathrm{O}+\mathrm{H}^{+}+\mathrm{SeO}_{4}{ }^{-} \leftrightarrow \equiv \mathrm{Cu}-\mathrm{O} \cdot \cdots \cdot \mathrm{HSeO}_{4}{ }^{-} \text {(hydrogen bond) } \\
& \equiv \mathrm{Cu}-\mathrm{OH}_{2}{ }^{+}+\mathrm{HSeO}_{4}{ }^{-} \leftrightarrow \equiv \mathrm{Cu}-\mathrm{OH}_{2}{ }^{+}-\mathrm{HSeO}_{4}{ }^{-} \text {(electrostatic attraction, low } \mathrm{pH} \text { ) }
\end{aligned}
$$

where $\equiv \mathrm{Cu}-\mathrm{O}(\mathrm{H})$ is the reactive group on the surface of copper-coated AC. Protonation of $\mathrm{SeO}_{4}{ }^{2-}$ and copper-coated AC surface could be the first step under the acidic condition. Selenate was then bound onto the surface of $\mathrm{AC}$ by electrostatic attraction, ion exchange, and/or hydrogen bonding to form an outer-sphere complex (Equations (1)-(5)). Similar mechanisms for selenate sorption onto iron oxides [45], chromate adsorption onto iron-coated AC [46], and iodide adsorption on copper modified AC [30] have been reported in previous studies. Hydrogen bond and both monodentate and bidentate inner sphere complexes under $\mathrm{pH}<7$ and a mixture of outer sphere and inner sphere complexes at $\mathrm{pH} 8$ were the possible mechanisms for selenate sorption onto iron-impregnated granular activated carbon [21].

\subsection{Adsorption Isotherm}

Additional adsorption experiments were conducted to probe adsorption isotherm of selenate onto AC with different $\mathrm{Cu}$ dosage coating (Figure 5). The results showed that a very low adsorption capacity with raw AC was obtained. It remarkably increased adsorption capacity after coating $\mathrm{Cu}$. The adsorption capacity gradually increased with increasing Cu-coating dosage. Similarly, the adsorption capacity gradually increased with increasing selenate concentration.

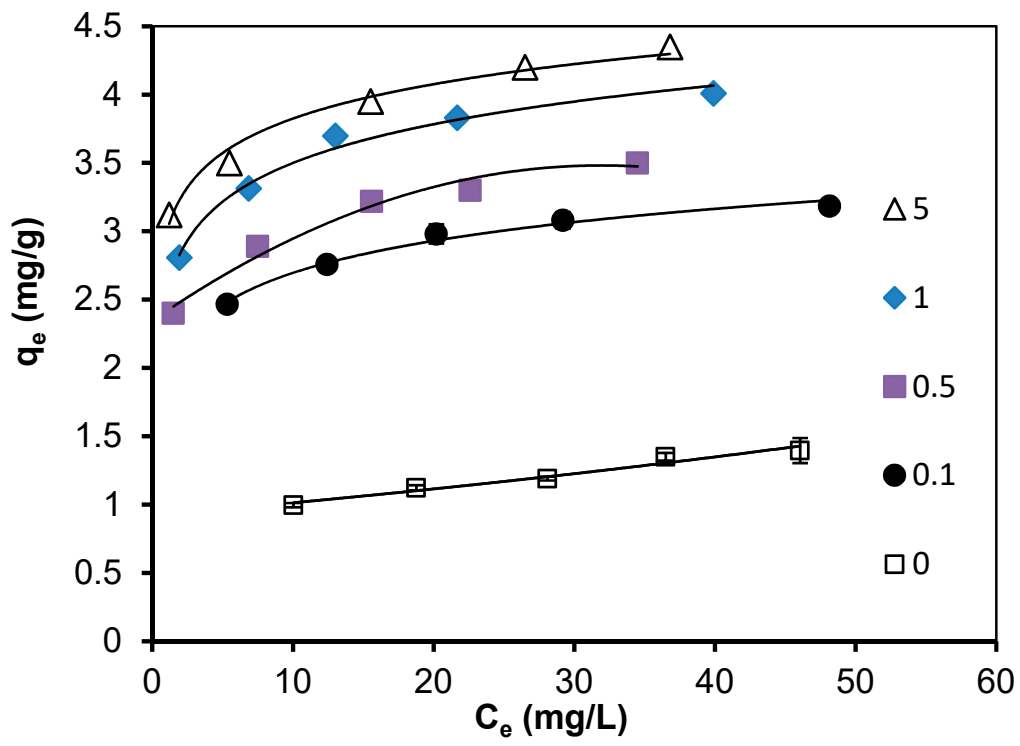

Figure 5. Adsorption isotherms of selenate onto activated carbon (AC) with different $\mathrm{Cu}$ dosage coating. 
Moreover, the Langmuir and Freundlich isotherms model were used to simulate the adsorption dynamics. The Langmuir model is given as below:

$$
\mathrm{q}_{\mathrm{e}}=\frac{\mathrm{QbC}_{\mathrm{e}}}{1+\mathrm{bC}_{\mathrm{e}}}
$$

where $\mathrm{q}_{\mathrm{e}}$ is the mass of selenate adsorbed per unit weight of adsorbent $(\mathrm{mg} / \mathrm{g}), \mathrm{C}_{\mathrm{e}}$ is the equilibrium concentration of selenate in the bulk solution $(\mathrm{mg} / \mathrm{L}), \mathrm{Q}$ is saturated adsorption capacity $(\mathrm{mg} / \mathrm{g})$, and b is the constant related to the free energy of adsorption. The constants of the Langmuir isotherm, $Q$ and $b$, were obtained by plotting $C_{e} / q_{e}$ versus $C_{e}$ in a linear regression analysis (Figure 6). The Freundlich isotherm can be described as below:

$$
\mathrm{q}_{\mathrm{e}}=\mathrm{K}_{\mathrm{f}} \mathrm{C}_{\mathrm{e}}^{1 / \mathrm{n}}
$$

where $K_{f}$ is the constant indicative of the relative adsorption capacity of the adsorbent (mg/g), and $1 / \mathrm{n}$ is the constant indicative of the intensity of the adsorption. The constants, $\mathrm{K}_{\mathrm{f}}$ and $1 / \mathrm{n}$, were obtained by plotting $\log \mathrm{q}_{\mathrm{e}}$ versus $\mathrm{C}_{\mathrm{e}}$ in a linear regression analysis (Figure 6).

The estimates of the Langmuir and Freundlich parameters are presented in Table 2.

Table 2. Constants of Langmuir and Freundlich equation.

\begin{tabular}{ccccccc}
\hline Adsorbent & \multicolumn{3}{c}{ Langmuir } & \multicolumn{3}{c}{ Freundlich } \\
\hline $\mathbf{( m m o l ~ C u / g ~ A C ) ~}$ & $\boldsymbol{Q}$ & $\boldsymbol{b}$ & $\mathbf{R}^{\mathbf{2}}$ & $\boldsymbol{K}_{\mathbf{f}}$ & $\mathbf{1} / \boldsymbol{n}$ & $\mathbf{R}^{\mathbf{2}}$ \\
\hline 0 & 1.36 & 0.136 & 0.998 & 0.585 & 0.2251 & 0.965 \\
0.1 & 3.32 & 0.450 & 0.999 & 2.036 & 0.1202 & 0.978 \\
0.5 & 3.56 & 0.524 & 0.999 & 2.215 & 0.1208 & 0.979 \\
1.0 & 4.23 & 0.721 & 0.999 & 2.625 & 0.1213 & 0.979 \\
5.0 & 4.48 & 0.801 & 0.997 & 2.815 & 0.1285 & 0.964 \\
\hline
\end{tabular}

According to the regression coefficients, the adsorption pattern fitted the Langmuir isotherm better than the Freundlich for all tested adsorbents (Figure 6), implying that homogeneous and monolayer sorption might be the dominant process. It was agreeable with previous study on iron-coated AC for selenite adsorption [35], copper-coated AC for propanethiol sorption [33], ceftazidime adsorption onto Cu-AC [24], and methylene blue dye sorption onto copper modified activated carbon [25]. As determined from the Langmuir isotherm, the maximum adsorption capacity (Q) for the AC modified with $0.1 \mathrm{mmol} \mathrm{Cu} / \mathrm{g}$ AC doubled that of the raw AC. Further increase of $\mathrm{Cu}$ loading, however, did not proportionally increase the value of $\mathrm{Q}$, and 3.56, 4.23, and $4.48 \mathrm{mg}$ Se/g was obtained for coating 0.5 , 1.0 , and $5.0 \mathrm{mmol} \mathrm{Cu} / \mathrm{g} \mathrm{AC}$, respectively. The maximum adsorption capacity of AC coating $1.0 \mathrm{mmol}$ $\mathrm{Cu} / \mathrm{g}$ for potential application is $4.23 \mathrm{mg} \mathrm{Se} / \mathrm{g}$, which is higher, in total, than selenite adsorption by iron-coated AC at 2.53-2.89 mg Se/g AC [35], selenate adsorption by iron-coated sand at $1.0 \mathrm{mg}$ Se/g sand [47], and selenate sorption to iron-coated AC at 0.28-0.42 $\mathrm{mg}$ Se/g [43] in previous studies. The maximum adsorption capacity $\left(K_{\mathrm{f}}\right)$, calculated from the Freundlich model, also showed substantial increase after $\mathrm{Cu}$ modification, almost quadruple from $0.585 \mathrm{mg} / \mathrm{g}$ of the raw $\mathrm{AC}$ to $2.036 \mathrm{mg} / \mathrm{g}$ of the treated AC with $0.1 \mathrm{mmol} \mathrm{Cu}$. However, only a small increase in $\mathrm{K}_{\mathrm{f}}$ was observed for higher copper coating AC. 

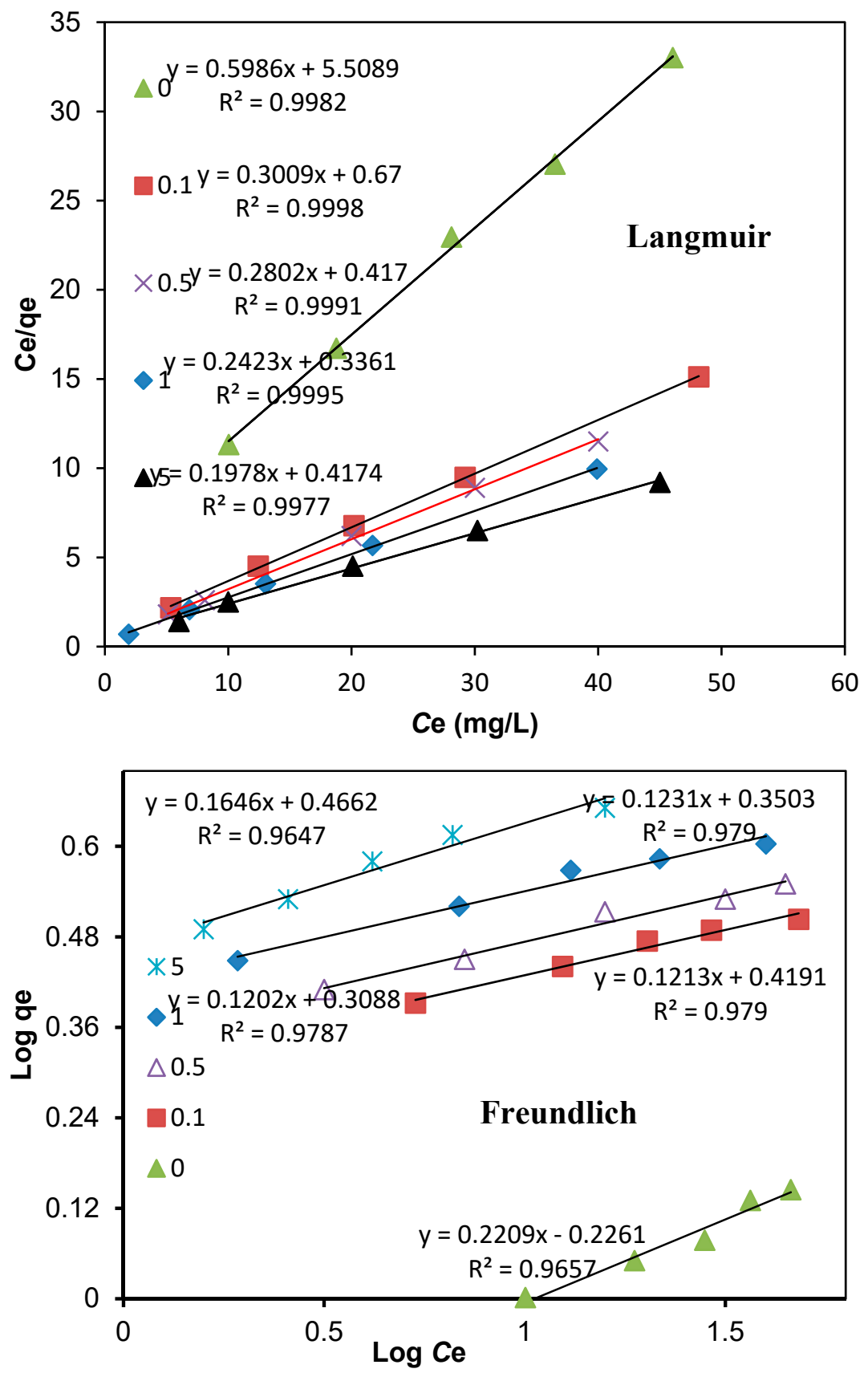

Figure 6. The Langmuir and Freundlich model for adsorption of selenate on copper modified AC.

\subsection{Desorption and Reuse Study}

The reversibility of the selenate adsorption onto the $\mathrm{Cu}$ - $\mathrm{AC}$ has been further studied using $0.10 \mathrm{M} \mathrm{NaOH}$ as the desorption agent. In order to completely recover the adsorbed selenate as well as regenerate the adsorbent for reuse, $4 \mathrm{~h}$ recommended by literature [31], $10 \mathrm{~h}, 20 \mathrm{~h}$, and $30 \mathrm{~h}$ of extracted time was performed. In Figure $7 \mathrm{a}$, the results showed that $90.5 \%, 92.4 \%, 96.8 \%$, and $97 \%$ of adsorbed selenate was recovered after 4, 10, 20, and $30 \mathrm{~h}$ extraction, respectively. A previous study showed that $4 \mathrm{~h}$ extraction achieved about $95 \%$ recovery of selenate adsorption onto iron oxides [28]. It indicated that selenate sorption onto $\mathrm{Cu}-\mathrm{AC}$ was more tightly than onto iron oxides. Thus, for $\mathrm{Cu}-\mathrm{AC}$ regeneration, $20 \mathrm{~h}$ extraction time is appropriate. The regenerated $\mathrm{AC}$ was reused for selenate sorption adjusting $\mathrm{pH} 7.0$ and the results showed that $79 \%$ and $76.7 \%$ selenate removal were achieved for the second and third run, respectively (Figure $7 \mathrm{~b}$ ). The performance was close to the first run of $84 \%$, 
indicating $\mathrm{Cu}-\mathrm{AC}$ is a reusable adsorbent for selenate removal and thus decreases its cost. Hydroxide is an inexpensive reagent, and the regeneration operation is simple. The spent adsorbent could be regenerated for reuse, and thus it could decrease its cost in application.
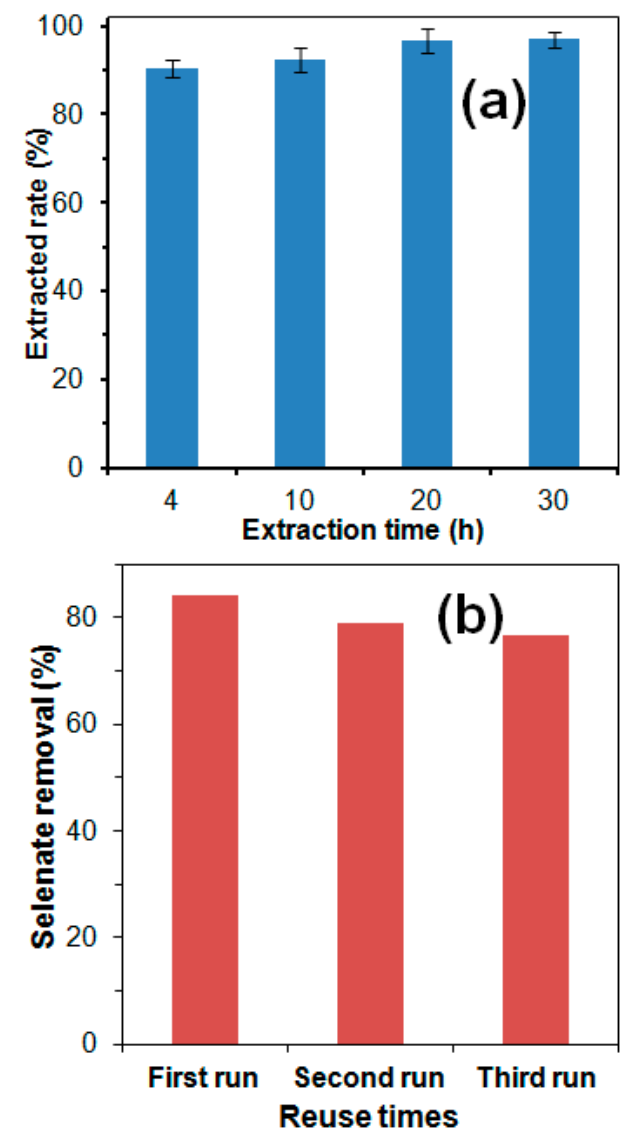

Figure 7. Effect of different extracted time on (a) adsorbed selenate desorption rate, and (b) the effect of reuse times on the performance of $1.0 \mathrm{mmol} / \mathrm{g} \mathrm{Cu}-\mathrm{AC}$.

\section{Conclusions}

Copper-coated AC adsorbents were prepared by simple precipitation process. The copper treatment significantly improved selenate adsorption capacity via changing the physicochemical properties of the AC surface. The modification changed the surface charge of the AC from highly negative to positive, and thus enhanced selenate adsorption through electrostatic attraction. The selenate adsorption was inhibited by high ionic strength and $\mathrm{pH}$. The adsorption pattern could be described better by the Langmuir than Freundlich model. Outer-sphere complexation through electrostatic attraction, ion exchange, and hydrogen bonding could be the primary mechanism for selenate fixation on the $\mathrm{Cu}-\mathrm{AC}$. An acceptable copper leaching for the AC modified with a loading of $\leq 1.0 \mathrm{mmol} \mathrm{Cu} / \mathrm{g}$ AC was observed by TCLP test on the spent sorbent. The used adsorbent could be effectively and easily regenerated by $\mathrm{NaOH}$ extraction for reuse. The regenerated $\mathrm{Cu}-\mathrm{AC}$ could be reused three times with only a litter decrease of removal efficiency.

Author Contributions: Conceptualization, C.T.; data curation, X.Z. and A.Z.; formal analysis, C.T., X.Z. and J.Z.; investigation, Q.W., X.H. and Y.W.; methodology, C.T. and X.Z.; validation, X.Z.; writing-original draft, X.Z.; writing-review and editing, C.T. All authors have read and agreed to the published version of the manuscript.

Funding: This research was funded by National Natural Science Foundation of China (21876097), Open Fund of Key Laboratory of Catalysis and Materials Science of the State Ethnic Affair Commission \& Ministry of Education (CHCL 16003), and the Yichang Research and Development Program of China (A18-302a-06). 
Acknowledgments: This work was supported by the National Natural Science Foundation of China (21876097), the Open Fund of Key Laboratory of Catalysis and Materials Science of the State Ethnic Affair Commission \& Ministry of Education (CHCL16003), the Yichang Research and Development Program of China (A18-302a-06). We also thank the anonymous reviewers for their comments on this manuscript.

Conflicts of Interest: The authors declare no conflict of interest.

\section{References}

1. He, Y.; Xiang, Y.; Zhou, Y.; Yang, Y.; Zhang, J.; Huang, H.; Shang, C.; Luo, L.; Gao, J.; Tang, L. Selenium contamination, consequences and remediation techniques in waterand soils: A review. Environ. Res. 2018, 164, 288-301. [CrossRef]

2. Qin, H.B.; Zhu, J.M.; Liang, L.; Wang, M.S.; Su, H. The bioavailability of selenium and risk assessment for human selenium poisoning in high-Se areas China. Environ. Int. 2013, 52, 66-74. [CrossRef]

3. Ullah, H.; Liu, G.; Yousaf, B.; Ali, M.U.; Irshad, S.; Abbas, Q.; Ahmad, R. A comprehensive review on environmental transformation of selenium: Recent advances and research perspectives. Environ. Geochem. Health 2019, 41, 1003-1035. [CrossRef]

4. Santos, S.; Ungureanu, G.; Boaventura, R.; Botelho, C. Selenium contaminated waters: An overview of analytical methods, treatment options and recent advances in sorption methods. Sci. Total Environ. 2015, 521, 246-260. [CrossRef] [PubMed]

5. Tan, L.C.; Nancharaiah, Y.V.; Hullebusch, E.D.; Lens, P.N.L. Selenium: Environmental significance, pollution, and biologicaltreatment technologies. Biotechnol. Adv. 2016, 34, 886-907. [CrossRef]

6. Winkel, L.H.E.; Johson, C.A.; Lenz, M.; Grundl, T.; Leupin, O.X.; Amini, M.; Charlet, L. Environmental selenium research: From microscopic processes to global understanding. Environ. Sci. Technol. 2012, 46, 571-579. [CrossRef] [PubMed]

7. Zhang, Y.Y.; Kuroda, M.; Arai, S.; Kato, F.; Inoue, D.; Ike, M. Biological treatment of selenate-containing saline wastewater by activated sludge under oxygen-limiting conditions. Water Res. 2019, 154, 327-335. [CrossRef] [PubMed]

8. Bailey, R.T. Review: Selenium contamination, fate, and reactive transportin groundwater in relation to human health. Hydrogeol. J. 2017, 25, 1191-1217. [CrossRef]

9. Johnson, P.I.; Gersberg, R.M.; Rigby, M.; Roy, S. The fate of selenium in the Imperial and Brawley constructed wetlands in the Imperial Valley (California). Ecol. Eng. 2009, 35, 908-913. [CrossRef]

10. Wong, S.; Ngadi, N.; Inuwa, I.M.; Hassan, O. Recent advances in applications of activated carbon from biowaste forwastewater treatment: A short review. J. Clean. Product. 2018, 175, 361-375. [CrossRef]

11. Pui, W.K.; Yusoff, R.; Aroua, M.K. A review on activated carbon adsorption for volatile organic compounds (VOCs). Rev. Chem. Eng. 2019, 35, 649-668. [CrossRef]

12. Korotta-Gamage, S.M.; Sathasivan, A. A review: Potential and challenges of biologically activated carbon toremove natural organic matter in drinking water purification process. Chemosphere 2017, 167, 120-138. [CrossRef] [PubMed]

13. Gopinath, A.; Kadirvelu, K. Strategies to design modified activated carbon fibers for thedecontamination of water and air. Environ. Chem. Lett. 2019, 16, 1137-1168. [CrossRef]

14. Pego, M.; Carvalho, J.; Guedes, D. Surface modification of activated carbon and its impact on application. Surf. Rev. Lett. 2019, 26, e1830006. [CrossRef]

15. Altintig, E.; Arabaci, G.; Altundag, H. Preparation and characterization of the antibacterial efficiency of silver loaded activated carbon from corncobs. Surf. Coat. Technol. 2016, 304, 63-67. [CrossRef]

16. Liu, Q.; Ke, M.; Yu, P.; Liu, F.; Hu, H.; Li, C. High performance removal of methyl mercaptan on metal modified activated carbon. Korean J. Chem. Eng. 2018, 35, 137-146. [CrossRef]

17. Zhou, K.; Ma, W.; Zeng, Z.; Ma, X.; Xu, X.; Guo, Y.; Li, H.; Li, L. Experimental and DFT study on the adsorption of VOCs on activated carbon/metal oxides composites. Chem. Eng. J. 2019, 372, 1122-1133. [CrossRef]

18. Wasewar, K.L.; Prasad, B.; Gulipalli, S. Removal of selenium by adsorption onto granular activated carbon (GAC) and powdered activated carbon (PAC). Clean 2009, 37, 872-883. [CrossRef]

19. Jegadeesan, G.; Mondal, K.; Lalvani, S.B. Comparative study of selenite adsorption on carbon based adsorbents and activated alumina. Environ. Technol. 2003, 24, 1049-1059. [CrossRef] 
20. Kwon, J.H.; Wilson, L.D.; Sammynaiken, R. Sorptive uptake of selenium with magnetite and its supported materialsonto activated carbon. J. Colloid Interface Sci. 2015, 457, 388-397. [CrossRef]

21. Zhang, N.; Gang, D.D.; McDonald, L.; Lin, L.S. Background electrolytes and pH effects on selenate adsorption usingiron-impregnated granular activated carbon and surface bindingmechanisms. Chemosphere 2018, 195, 166-174. [CrossRef] [PubMed]

22. Dobrowolski, R.; Otto, M. Preparation and evaluation of Fe-loaded activated carbon for enrichment of selenium for analytical and environmental purposes. Chemosphere 2013, 90, 683-690. [CrossRef]

23. Boutillara, Y.; Tombeur, J.L.; Weireld, G.D.; Lodewyckx, P. In-situ copper impregnation by chemical activation with $\mathrm{CuCl}_{2}$ and itsapplication to $\mathrm{SO}_{2}$ and $\mathrm{H}_{2} \mathrm{~S}$ capture by activated carbons. Chem. Eng. J. 2019, 372, 631-637. [CrossRef]

24. Hu, X.; Zhang, H.; Sun, Z.R. Adsorption of low concentration ceftazidime from aqueous solutionsusing impregnated activated carbon promoted by iron, copper andaluminum. Appl. Surf. Sci. 2017, 392, 332-341. [CrossRef]

25. Li, C.; Xia, H.; Zhang, L.; Peng, J.; Cheng, S.; Shu, J.; Zhang, S. Kinetics, thermodynamics, and isotherm studyon the removal of methylene blue dye by adsorptionvia copper modifed activated carbon. Res. Chem. Intermed. 2018, 44, 2231-2250. [CrossRef]

26. Peternela, J.; Silva, M.F.; Vieira, M.F.; Bergamasco, R.; Vieira, A.M.S. Synthesis and Impregnation of Copper Oxide Nanoparticles on Activated Carbon through Green Synthesis for Water Pollutant Removal. Mater. Res. 2018, 21, e20160460. [CrossRef]

27. Zhang, C.; Song, W.; Zhang, X.; Li, R.; Zhao, S.; Fan, C. Synthesis and evaluation of activated carbon spheres with coppermodifcation for gaseous elemental mercury removal. J. Porous Mater. 2019, 26, 693-703. [CrossRef]

28. Shu, J.H.; Cheng, S.; Xia, H.Y.; Zhang, L.; Peng, J.H.; Li, C.; Zhang, S. Copper loaded on activated carbon as an efficient adsorbent for removal of methylene blue. RSC Adv. 2017, 7, 14395-14405. [CrossRef]

29. Dashamiri, S.; Ghaedi, M.; Asfaram, A.; Zare, F.; Wang, S.B. Multi-response optimization of ultrasound assisted competitiveadsorption of dyes onto $\mathrm{Cu}(\mathrm{OH})_{2}$-nanoparticle loaded activated carbon: Central composite design. Ultrason. Sonochem. 2017, 34, 343-353. [CrossRef]

30. Zhang, X.; Gu, P.; Li, X.; Zhang, G. Efficient adsorption of radioactive iodide ion from simulated wastewaterby nano $\mathrm{Cu}_{2} \mathrm{O} / \mathrm{Cu}$ modified activated carbon. Chem. Eng. J. 2017, 322, 129-139. [CrossRef]

31. Jackson, B.P.; Miller, W.P. Effectiveness of phosphate and hydroxide for desorption of arsenic and selenium species from iron oxides. Soil Sci. Soc. Am. J. 2000, 64, 1616-1622. [CrossRef]

32. Jegadeesan, G.; Mondal, K.; Lalvani, S.B. Adsorptive of Se(IV) and Se(VI) using copper-impregnated activated carbon and fly ash-extracted char carbon. Water Air Soil Pollut. 2015, 226, 234-246. [CrossRef]

33. Moreno-Piraján, J.C.; Tirano, J.; Salamanca, B.; Giraldo, L. Activated carbon modified with copper for adsorption of propanethiol. Int. J. Mol. Sci. 2010, 11, 927-942. [CrossRef] [PubMed]

34. Singh, N.; Balomajumder, C. Simultaneous removal of phenol and cyanide from aqueous solutionby adsorption onto surface modified activated carbon prepared fromcoconut shell. J. Water Process Eng. 2016, 9 , 233-245. [CrossRef]

35. Zhang, N.; Lin, L.S.; Gang, D. Adsorptive selenite removal from water using iron-coating GAC adsorbents. Water Res. 2008, 42, 3809-3816. [CrossRef] [PubMed]

36. Park, S.J.; Jang, Y.S. Pore structure and surface properties of chemically modified activated carbon for adsorption mechanism and rate of Cr(VI). J. Colloid Interface Sci. 2002, 249, 458-463. [CrossRef]

37. Norouzi, S.; Heidari, M.; Alipour, V.; Rahmanian, O.; Fazlzadeh, M.; Mohammadi-moghadam, F.; Nourmoradi, H.; Goudarzi, B. Preparation, characterization and $\mathrm{Cr}(\mathrm{VI})$ adsorption evaluation of $\mathrm{NaOHactivated} \mathrm{carbon} \mathrm{produced} \mathrm{from} \mathrm{Date} \mathrm{Press} \mathrm{Cake;} \mathrm{an} \mathrm{agro-industrial} \mathrm{waste.} \mathrm{Bioresour.} \mathrm{Technol.}$ 2018, 258, 48-56. [CrossRef]

38. Al-Lagtah, N.M.A.; Al-Muhtaseb, A.H.; Ahmad, M.N.M.; Salameh, Y. Chemical and physical characteristics of optimal synthesised activatedcarbons from grass-derived sulfonated lignin versus commercialactivated carbons. Microporous Mesoporous Mater. 2016, 225, 504-514. [CrossRef]

39. Ma, F.; Li, P.; Zhang, B.; Wang, Z. The facile synthesis of a chitosan Cu(II) complex by solution plasmaprocess and evaluation of their antioxidant activities. Int. J. Biol. Macromol. 2017, 103, 501-507. [CrossRef] 
40. Sharma, S.; Uttam, K.N. Rapid analyses of stress of copper oxide nanoparticles on wheat plants at an early stage by laser induced fluorescence and attenuated total reflectance Fourier transform infrared spectroscopy. Vib. Spectrosc. 2017, 92, 135-150. [CrossRef]

41. Ho, H.P.; Kasinathan, P.; Kim, J.; Lee, D.; Woo, H.C. Deep desulfurization of fuel gas by adsorption on Cu-impregnated activated carbons in practical conditions. Korean J. Chem. Eng. 2016, 33, 1908-1916. [CrossRef]

42. Szlachta, M.; Chubar, N. The application of Fe-Mn hydrous oxides based adsorbent for removing selenium species from water. Chem. Eng. J. 2013, 217, 159-168. [CrossRef]

43. Zhang, N.; Gang, D.; Lin, L.S. Adsorptive removal of parts per million level selenate using iron-coated GAC adsorbents. J. Environ. Eng. 2010, 136, 1089-1095. [CrossRef]

44. Hayes, K.F.; Papelis, C.; Leckie, J.O. Modeling ionic strength effects on anion adsorption at hydrous oxide/solution interfaces. J. Colloid Interface Sci. 1988, 125, 717-726. [CrossRef]

45. Rovira, M.; Giménez, J.; Martínez, M.; Martínez-Lladó, X.; Pablo, J.; Duro, M.L. Sorption of selenium (IV) and selenium (VI) onto natural iron oxides: Goethite and hematite. J. Hazard. Mater. 2008, 150, 279-284. [CrossRef]

46. Liu, W.; Zhang, J.; Zhang, C.; Wang, Y.; Li, Y. Adsorptive removal of Cr(VI) by Fe-modified activated carbon from Trapanatans husk. Chem. Eng. J. 2010, 162, 677-684. [CrossRef]

47. Lo, L.; Chen, T.Y. Adsorption of Se(IV) and Se(VI) on an iron-coated sand from water. Chemosphere 1997, 35, 919-930. [CrossRef]

(C) 2020 by the authors. Licensee MDPI, Basel, Switzerland. This article is an open access article distributed under the terms and conditions of the Creative Commons Attribution (CC BY) license (http://creativecommons.org/licenses/by/4.0/). 